\title{
Blurring the Beginning of Non-International Armed Conflict: The Frustration of Legal Paradigms in Response to Terrorism
}

\author{
Sean Shun Ming Yau
}

DOI: $10.21827 / 5 a 6 a f a 1 c 15 c 57$

\author{
Keywords \\ INTERNATIONAL HUMANITARIAN LAW; NON-INTERNATIONAL ARMED \\ CONFLICT; LAW ENFORCEMENT; TERRORISM; COUNTER-TERRORISM; \\ APPLICABILITY OF IHL
}

\begin{abstract}
The past decades have seen an increasing amount of intra-State wars unfold. The term 'terrorism' has increasingly become a license for States to unilaterally conduct their action. Because of that, determining the applicable legal norms that delimit the State's military power and regulate the warring parties' conducts is of ultimate importance. Although the legal test for the applicability of international humanitarian law in noninternational armed conflict has been largely settled - first found in the second Protocol additional to the Geneva Convention and second supplemented by international tribunals as declaratory of customary IHL - terrorism has caused much frustration in the course of such legal determination, not helped by the obscure facts on the ground. This article will argue that by subjectively classifying a situation as 'terrorism' the State has not displaced the applicability question. In fact, the impact that terrorism has on the legal assessment is minimal, if any.
\end{abstract}

\section{Introduction}

Traditionally, law enforcement is for States to regulate violence occurring within its domestic sphere. If such violence escalates to a sufficient intensity between the State and an organised armed group, the situation may fall under the ambit of international humanitarian law (IHL). The applicability of IHL is definable by the legal existence of an armed conflict. Today, asymmetrical warfare and terrorism have drastically changed the academic discourse because the search for an 'armed conflict' is no longer so clear-cut. It thus leaves much political discretion for States to opt for a law enforcement paradigm in response to terrorism.

This article will examine the impact that terrorism has on the legal establishment of non-international armed conflict (NIAC). The need to focus on NIAC is manifested in the frequent commission of terrorist acts and the label of '(counter-)terrorism' in these situations. It will begin by recalling the essential elements in establishing NIAC and the challenges that can already be identified in relation to terrorism. The article will then go on to discuss the relationship between IHL and law enforcement with regard to terrorism. Most often, the State's choice has frustrated the applicable paradigms. Lastly, this analysis will show that such a frustration comes from a lack of understanding of the role of terrorism in establishing NIAC.

Judicial Clerk/Intern to Judge Morrison, Appeals Chamber, International Criminal Court; LL.M., Leiden University; LL.B. (Hons), The University of Hong Kong. The author can be reached at s.m.yau@umail.leidenuniv.nl. The views expressed in this article do not reflect the opinion of the International Criminal Court. 


\section{The Beginning of a Non-International Armed Conflict}

In search for the correct legal paradigm applicable to a situation of terrorism, it is necessary to first address the question of whether IHL is applicable, that is, whether an armed conflict can be legally established. It is proper to inquire firstly into IHL's applicability because in an armed conflict, IHL prevails over a national legal framework. ${ }^{1}$ Article 2(2) of the second Additional Protocol to the Geneva Conventions (AP II) negatively defines a NIAC by excluding violence of insufficient intensity.

To determine the existence of a NIAC, the sources of law include treaty law and customary IHL. The latter has been interpreted and applied by the International Criminal Tribunal for the Former Yugoslavia (ICTY) in the Tadic decision. Despite the clear nonexhaustive list of indicators provided by the Appeals Chamber, difficulties abound, the situation is not helped by the fact that terrorist acts often possess characteristics that make the evidence on the ground obscure.

\section{A. Treaty Law}

The starting point in treaty law to define NIAC can be found in Common Article 3 of the Geneva Conventions. ${ }^{2}$ It refers to 'armed conflict not of an international character occurring in the territory of one of the High Contracting Party'. Depending on the situation at hand, hostilities may occur between governmental armed forces and nonState armed groups, or between such groups only.

Separately, Article 1 of the AP II excludes from NIAC 'situations of internal disturbance and tensions, such as riots, isolated and sporadic acts of violence and other acts of a similar nature. ${ }^{3}$ Instead, AP II offers a narrow definition of NIAC - the armed conflict shall:

take place in the territory of a High Contracting Party between its armed forces and dissident armed forces or other organised armed groups which, under responsible command, exercise such control over a party of its territory as to enable them to carry out sustained and concerted military operations and to implement this Protocol.

This enunciates a more restrictive scope than Common Article 3. Firstly, it contains the cumulative requirements for responsible command ${ }^{4}$ and territorial $\operatorname{control}^{5}$ by the non-

1 International Committee of the Red Cross (ICRC), 'Report on International Humanitarian Law and the Challenges of Contemporary Armed Conflicts', 31st International Conference of the Red Cross and Red Crescent (2011), 49. Some scholars have called IHL the lex specialis in armed conflict. See e.g.. Gill, $\mathrm{T}$, 'Some Thoughts on the Relationship Between International Humanitarian Law and International Human Rights Law: A Plea for Mutual Respect and a Common-Sense Approach' 16 Yearbook of International Humanitarian Law (YIHL) (2013) 251-252.

2 There remains in the ICTY's jurisprudence to be a need for a responsible command: International Criminal Tribunal for the former Yugoslavia (ICTY), Prosecutor v. Enver Hadzïhasanovic and Others (Appeals Chamber, Decision on interlocutory Appeal Challenging Jurisdiction in Relation to Command Responsibility), ICTY-01-47-AR72 (16 July 2003) 11.

3 AP II, Article 1(2). Also see Pedrazzi, M, 'The beginning of IAC and NIAC for the purpose of the applicability of IHL' at the Sanremo Roundtable: 'The Distinction between International and NonInternational Armed Conflicts: Challenges for IHL?', at 7.

4 There remains, in the ICTY's jurisprudence to be, a need for a responsible command: ICTY, Prosecutor v. Enver Hadzïhasanovic and Others (Decision on Interlocutory Appeal Challenging Jurisdiction in Relation to Command Responsibility) Case No. IT-01-47-AR72 (16 July 2003) at 11 and ff.

5 The common view is that the group only needs to control the portion of territory sufficient to enable them carrying out sustained and concerted military operations. See ICRC Opinion Paper, 'How is the Term 'Armed Conflict' Defined in International Humanitarian Law?' (March, 2008), 4. It has also been 
State armed groups. Second, it excludes conflicts arising solely between non-State armed groups but envisages the involvement of governmental forces. ${ }^{6}$ Lastly, the words 'in the territory of a High Contracting Party between its armed forces' implies that, in order for IHL to apply to a State's armed forces, those forces must be present in the territory of that State. ${ }^{7}$ Hence, it undermines the applicability of IHL to State armed forces operating extraterritorially.

It is noted, however, that the more restrictive criteria present in AP II do not in any way modify the content of Common Article $3 .{ }^{8}$ Rather, the definitions of both regimes are complementary, the differences of which had later been brought closer by the Tadić decision. ${ }^{9}$

\section{B. The Tadić Decision ${ }^{10}$}

The often-cited Tadic decision is instrumental in elaborating on the content of Common Article 3. Considered to propound the legal norms in Common Article 3 as reflective of customary IHL, ${ }^{11}$ the Appeals Chamber interpreted NIAC as a situation of "protracted armed violence between governmental authorities and organised armed groups or between such groups within a State. ${ }^{12}$ This formulation has a two-pronged test of thresholds as to: 1 . the intensity of violence and 2. the degree of organisation of the nonState armed group. ${ }^{13}$

suggested that the territory does not have to be substantial nor the control stable: see e.g., ICRC Commentary AP II, 4464-7; and Prosecutor v. Akayesu (Appeals Chamber, Judgment) ICTR-96-4-A (1 June 2001) 626.

6 Schindler, D, 'The Different Types of Armed Conflicts According to the Geneva Conventions and Protocols' (1979-II) 163 Recueil des Cours 131, 148-149.

7 Pejić, J, 'The Protective Scope of Common Article 3: More than Meets the Eye', 93(881), ICCR (2011) 189-199; Lubell, N, Extraterritorial Use of Force against Non-State Actors (Oxford University Press 2010) 100 .

8 ICRC Opinion Paper, supra nt 5; Milanović, M and Hadzi-Vidanovic, V, "A Taxonomy of Armed Conflict" in White, N, and Henderson, C, eds, Research Handbook on International Conflict and Security Law (Edward Elgar Pub. Ltd 2012) 286.

9 Abi-Saab, G, "Non-International Armed Conflicts" in Baxter, R and Pilloud, C, eds, International Dimensions of Humanitarian Law (UNESCO 1988) 229.

10 Note that Article 8(2)(f) of the Rome Statute provides for a similar definition. The Tadic formulation was also adopted by the ICC in the case Prosecutor v. Thomas Lubanga Dylio, (Trial Chamber, Decision on the Confirmation of Charges) ICC-01/04-01/06 (29 January 2007) para 234.

11 The Trial Chamber stated that 'the International Tribunal is not called upon to apply conventional law but instead is mandated to apply customary international law.' Prosecutor $v$ Tadic (Trial Chamber Judgment) IT-94-1-AR72 (2 October 1995) para 60. See also, e.g. ICTY, The Prosecutor v. Ramush Haradinaj, Idriz Balaj and Lahi Brahimaj (Haradinaj et al.) (Trial Chamber Judgment) ICTY-04-84-T (3 April 2008): '[t]he rules contained in Common Article 3 are part of customary international law applicable in non-international armed conflict'; ICJ, Application of the Convention on the Prevention and Punishment of the Crime of Genocide (Bosnia and Herzegovina v. Serbia and Montenegro), Judgement of 26 February 2007, paras 406-407.

12 ICTY, Prosecutor v. Dusko Tadić, (Appeals Chamber, Decision on the Defence Motion for Interlocutory Appeal on Jurisdiction) ICTY-94-1-A (2 October 1995) para 70. The Tadic interpretation has been accepted as custom by ICC in International Criminal Court (ICC), Prosecutor v. Thomas Lubanga Dylio, (Trial Chamber, Decision on the Confirmation of Charges) ICC-01/04-01/06 (29 January 2007) para 233. See generally, Sivakumaran, S, The Law of Non-International Armed Conflict (Oxford University Press 2012).

13 ICRC has adopted the same legal test: see ICRC Opinion Paper, supra nt 5. 


\section{i. Intensity of Violence}

In determining the intensity of violence, the ICTY has laid down numerous factors. In the leading case of Prosecutor v. Ramush Haradinaj, concerning the conflict between the Federal Republic of Yugoslavia and Kosovo Liberation Army, the Trial Chamber took into consideration inter alia the number, protraction, and intensity of individual confrontation; the types of weapons and other military equipment used; the number of persons and types of forces partaking in the fighting; and the number of casualties. ${ }^{14}$ It is worth noting that terrorist acts may also be factored in this intensity threshold, which will be discussed in the next section.

These indicative factors are nonetheless non-exhaustive, as one still needs to proceed to assess the existence of a NIAC by reference to the overall context. ${ }^{15}$ It is an objective determination without the need to resort to the State's declaration. ${ }^{16}$

\section{ii. Degree of Organisation of Non-State Armed Groups}

The ICTY has also set out useful indicators to determine whether a certain non-State armed group is sufficiently organised to be considered a party to an armed conflict. These include, inter alia, the existence of a command structure within the group; its control over a certain territory; its ability to gain access to weapons, other military equipment, recruits and military training; and its ability to plan, coordinate and carry out military operations, including troop movements and logistics. ${ }^{17}$ As far as terrorism is concerned, the motivation of or the purpose advanced by the group is irrelevant. ${ }^{18}$

In the situation of Syria, the main opposition armed group, the Free Syrian Army, is composed of insurgents who have carried out coordinated attacks. They were capable of controlling certain parts of the territory, including northern Syrian and towns around Damascus. ${ }^{19}$ An opposite example is Al-Qaeda, which does not control a certain territory and operates across borders. ${ }^{20}$

\section{Challenges of Establishing the Existence of NIACs}

At this stage, we can already identify profound difficulties in establishing the existence of NIAC from the Tadic formulation. Further, each of the two criteria can be prone to the terrorist aspect of a conflict.

At the outset, the Haradinaj case requires that a non-State armed group must achieve the requisite degree of organisation so that it can engage in military activities of a certain intensity but not merely sporadic attacks. At times, States would subjectively classify a group as 'rebels' or 'terrorists'. In the past, these were the Kurdistan Workers'

14 ICTY, The Prosecutor v. Ramush Haradinaj, Idriz Balaj and Lahi Brahimaj (Haradinaj et al.), (Trial Chamber Judgment) ICTY-04-84-T (3 April 2008) para 49.

15 See ICTY, Prosecutor v. Fatmir Limaj et al., (Trial Chamber Judgment) ICTY-03-66-T (30 November 2005) para 86. The Inter-American Commission of Human Rights (IACHR) held that a confrontation lasting thirty hours between the Argentinian military and dissident soldiers was covered by Common Article 3 in Inter-American Court of Human Rights (IACHR), Abella v. Argentina, Case No. 11.137, Report No. 55/97 (18 November 1997).

16 Under the same rationale, the fact that a State announces public emergency derogation from human rights treaties is irrelevant.

17 ICTY, The Prosecutor v. Ramush Haradinaj, Idriz Balaj and Lahi Brahimaj (Haradinaj et al.), (Trial Chamber Judgement) ICTY-04-84-T (3 April 2008) para 60.

18 Akande, D, 'Classification of Armed Conflicts: Relevant Legal Concepts' in Wilmshurst, E, ed., International Law and the Classification of Conflicts (Oxford University Press 2012) 52.

19 Grignon, J, 'The beginning of application of international humanitarian law: A discussion of a few challenges' (2014) 96 IRRC 893, 156.

20 Brooks, R, 'Protecting Rights in the Age of Terrorism: Challenges and Opportunities' 36 Georgetown Journal of International Law (2005) 669, 675. 
Party in Turkey, ${ }^{21}$ the Revolutionary Armed Forces of Colombia in Colombia ${ }^{22}$ and the Liberation Tigers of Tamil Eelam in Sri Lanka. ${ }^{23}$ But again, a State's declaration has no legal impact on the qualification of the parties to a conflict.

Rather, a question that often baffles international lawyers is how far we can include a non-State armed group's affiliates. IHL does not have a clear answer. Pejić looks at whether the affiliation to the core group is merely ideological or if military operations can be autonomously conducted by the affiliates. ${ }^{24}$ In the second situation, the affiliates may be deemed 'co-belligerents' in the same armed conflict. ${ }^{25}$ In the example of Al-Qaeda, its structure has been increasingly decentralised and degraded. The fact that its offshoots were involved in sporadic attacks in Iraq or Yemen does not warrant the conclusion that one single NIAC exists on its own. ${ }^{26}$ In the words of Milanović, one simply cannot aggregate all terrorist acts motivated by Islamic fundamentalism coupled with professed allegiance to Al-Qaeda all across the world in order to satisfy the twofold intensity and organization test. ${ }^{27}$

Another difficulty arising from Common Article 3 are situations involving crossborder violence. With regard to an established armed conflict, the issue of how to categorise spill-over violence into a neighbouring State appears to remain uncertain. This is the case for the Al-Shabaab militia from Somalia on the Kenyan territory, Colombia's fighting with the members of the Revolutionary Armed Forces of Colombia on the Ecuadorian territory and the Kurdish armed struggle for independence against Iran and Turkey. Both Common Article 3 and the Appeals Chamber in Tadić refer the existence of a NIAC to violence coming from one single State. The next natural implication is that spill-over violence countered by the neighbouring State would result in a separate, parallel NIAC. But what if the new NIAC does not independently reach the intensity threshold?

Under international law, the mere fact that an international border has been crossed does not absolve the parties of their IHL obligations, much less permitting the deprivation of civilian protection. ${ }^{28}$ In a situation where the non-State armed group from State A crosses the border to the territory of State B, there are two possibilities. First, if the sporadic violence within State B is in itself insufficient to trigger the application of IHL, domestic legal orders would fill the regulatory gap. ${ }^{29}$ Second, in case a sufficient nexus can be established between the military operations in State B and the ongoing NIAC in State A, those operations can nonetheless be attributed to become part of the overall armed conflict. ${ }^{30}$ In a similar vein, the ICTY Appeals Chamber has stated that,

21 In 2005, Turkey claimed that the violence with the PKK was a matter of law enforcement against a terrorist organisation: see Letter from Ambassador Türkekul Kurttekin in response to the characterisation of the PKK, Landmine Monitor Report, 15 December 2005.

22 Colombia did not recognise a state of war, but recognised IHL applicability in 1999: see Intervention of President Uribe, Forum on 'Internal Conflict or Terrorist Threat?', Chía, Colombia, 26 April 2005, quoted in Roa-Castro, D, 'Mine Action in the Midst of Internal Conflict: The Colombian Case' in Geneva Call, Mine Action in the Midst of Internal Conflict (2005) 17.

23 Political Committee of the LTTE, Special Press Release, 10 October 1997.

24 Pejić, J, 'Extraterritorial targeting by means of armed drones: some legal implications' (2014), 96 IRRC $893,83$.

25 Ibid.

26 Lubell, N, 'The War against Al-Qaeda' in E. Wilmshurst (ed.), International Law and the Classification of Conflicts (2012) 451-452.

27 Milanović, M, 'The end of application of international humanitarian law', (2014) 96 IRRC 893, 187.

28 Pejić, J, supra nt 24, 107, 194.

29 Milanović and Hadzi-Vidanovic, supra nt 8, 290.

$30 I d, 291$ : 'organic or structural link between the sporadic extraterritorial outbreaks of violence and the main body of the conflict.' 
one can merge the cross-border violence if it is 'closely related to the hostilities occurring in other parts of the territories controlled by the parties to the conflict' ${ }^{31}$ The Taliban fighting that spread from Afghanistan onto the Pakistani territory is a case in point.

\section{The Legal Relationship Between IHL, Law Enforcement and Terrorism}

It is proper now to introduce law enforcement given the extent to which it might confuse the applicability of IHL. The challenges of establishing the existence of a NIAC for IHL to apply are heightened by the State's desire to prioritise law enforcement. As a matter of applicable paradigms, although IHL and law enforcement can theoretically be coextensive, they do provide competing protection standards. Insofar as a counter-terrorism operation is conducted within the realm of law enforcement, it does not immediately negate the classification of the situation as a NIAC. ${ }^{32}$ From the perspective of the sovereign State, specific rules governing a conflict situation must be selected. This frontline discretion left to the State to decide the applicable paradigm as they see fit often leads to collateral ramifications. ${ }^{33}$ In the view of the International Committee of the Red Cross (ICRC), 'the law is not a question of choice, but based on the situation. ${ }^{34}$ It added that:

They [the authorities] cannot choose to switch freely from one legal framework to the other as it suits them. The application will depend on objective criteria as to whether the overall situation qualifies as an armed conflict or not and whether the action taken is directed against a legitimate target and can therefore be considered as part of the conduct of hostilities or as a normal law enforcement activity. ${ }^{35}$

For this reason, we will now look at the competing nature of IHL and law enforcement as legal paradigms in response to terrorism, and some examples of their frustrated application.

\section{A. Differentiating IHL and Law Enforcement}

At risk of oversimplification, law enforcement denotes the legal regime containing a set of legal norms applicable during law enforcement operations. These norms are often times derivable from domestic legal orders and encompass, in particular for our purposes, criminal law provisions prohibiting terrorist offences, constitutional law ensuring human rights protection and administrative law which delimits the scope of authority of the State agent. One can further distil the law applicable to law enforcement from international law, including international human rights law (IHRL) ${ }^{36}$

Tadić, supra nt 11 , para 70.

Akande, D, supra nt 18,53 .

33 ICRC, Violence and Use of Force (2015), 399: 'for political reasons, authorities may deny the fact that their country is in a situation of non-international armed conflict, while at the same time deploying military means to neutralize and kill their adversaries.'

34 ICRC, To Serve and to Protect: Human Rights and Humanitarian Law for Police and Security Forces (2014), 398.

35 Ibid.

36 See generally, Krähenmann, S, 'Foreign Fighters under International Law and National Law' 20 Recueils de la Societe Internationale de Droit Penal Militaire et de Droit de la Guerre 249 (2015), for international treaties relating to counter-terrorism. 
In principle, IHL and law enforcement bear marked differences. Firstly, IHL is characterised by a horizontal relationship between parties to the conflict. ${ }^{37}$ The ultimate aim of military operations is to prevail over the enemy's armed forces, ${ }^{38}$ whereas under law enforcement the relationship between the State and individuals is vertical, typical of the enforcement of domestic legislation. ${ }^{39}$ Although law enforcement agents can derogate from human rights in "emergency" situations, ${ }^{40}$ one cannot simply shift the scope and content of obligations by rhetorically avoiding the IHL paradigm. This is despite the blurred separation in practice when the same State agency has the authority to carry out both hostilities and law enforcement activities. ${ }^{41}$

Secondly, the two paradigms answer the question of the applicability of legal norms at differing stages. By placing counter-terrorism responses in a purely terrorism context, the legal norms of the law enforcement paradigm - often a mix of IHRL and domestic criminal law - automatically apply and guide the subsequent judicial assessment on any human rights violations. The applicability of IHL, on the other hand, depends on the existence of an armed conflict, which is a legal determination ex post facto by a competent judicial body. ${ }^{42}$

Lastly, from a protection perspective, IHL and law enforcement entail discrepancies in their protection standards. Take detention incommunicado as an example. Under IHL, holding persons at 'black sites' is only lawful if necessary for military advantages in relation to and for the duration of the conflict at hand. ${ }^{43}$ Detainees shall be tried before an independent and impartial military tribunal and be repatriated as soon as the hostilities end. ${ }^{44}$ In a NIAC situation, in addition to the Common Article 3 standards, AP II lays down fundamental guarantees for the treatment of detainees. ${ }^{45} \mathrm{In}$ contrary, IHRL requires detention to be necessary and proportionate to preventing a person's commission of offences or for prosecution purposes. ${ }^{46}$ Holding a person incommunicado, however, is unlawful by definition due to the lack of procedural guarantees relating to the right to liberty and associated fair trial rights. ${ }^{47}$

37 On the equality of belligerents, see e.g., Clapham, A, and Gaeta, P, The Oxford Handbook of International Law in Armed Conflict (Oxford University Press 2014) 52: 'To a large extent, the law of armed conflict can only practically function if it is premised on the equality and non-discrimination of the belligerents.'

$38 \quad I d, 395$.

39 Römer, J, Killing in a Gray Area between Humanitarian Law and Human Rights (Springer 2010) 37.

40 Chadwick, E, Self-Determination, Terrorism, and the International Humanitarian Law of Armed Conflict, (Martinus Nijhoff Publishers 1996) 135.

41 Ibid.

42 ICTY, Prosecutor v. Dario Kordic and Mario Cerkez (Pre-Trial Chamber, Decision on the Joint Defense Motion to Dismiss the Amended Indictment for Lack of Jurisdiction Based on the Limited Jurisdictional Reach of Articles 2 and 3) IT-95-14/2-PT (2 March 1999) paras. 14-16.

43 For a detailed distinction between detention under IHL and LE, see e.g., Weissbrodt, D, and Bergquist, A, 'Extraordinary Rendition: A Human Rights Analysis', 19 Harvard Human Rights Journal (2006) 123,148 (noting that inhumane treatment may include 'cut[ting] prisoners of war off completely from the outside world,' especially from their families). See also, Hamdi v. Rumsfeld, 542 U.S. 507, 2004, paras 518-524.

44 Geneva Convention III, Article 118.

45 Additional Protocol II, Article 4 on humane treatment of persons detained, and Article 5 on minimum provisions for the treatment of persons interned, detained or deprived of their liberty for reasons related to the armed conflict).

46 See ICCPR, Article 9 and ECHR, Article 5.

47 See ICCPR, Article 9(3); ECHR, Article 5(3), Article 6. 


\section{B. The Significance of the Applicability Question}

Clearly, the question of which paradigm is applicable to the situation at hand is necessary to determine the set of legal norms when later adjudicating on specific legal issues. The distinct ways of prosecuting terrorists in each paradigm has direct bearing on the postconflict transitional justice through accountability of all parties concerned. During an armed conflict, where IHL (and IHRL with certain restrictions) ${ }^{48}$ is applicable, attacks towards military personnel and objectives may be lawful, provided that the means employed does not cause unnecessary suffering to the enemy's soldiers. ${ }^{49}$ This is regardless of whether the attack is performed by the State or the non-State armed group, in line with the principle of equality of belligerents. ${ }^{50}$

Terrorist acts committed by either party to a NIAC and in connection with the armed conflict are considered a grave breach to the AP II and customary IHL and thus, they are prosecuted as war crimes. ${ }^{51}$ More specifically, Article 4(2)(d) and Article 13(2) of the AP II provide that violent acts intended to spread terror among a civilian population or individuals are prohibited 'at any time and in any place'. It should be noted, as it has been specified in Articles 3(d) and 4(d) of the Statute of the Special Court for Sierra Leone (SCSL), that terrorist acts are a serious violation of AP II and Common Article 3 applicable to NIAC. The jurisprudence of the SCSL also reflects this position. ${ }^{52}$

On the other hand, in a situation falling short of an armed conflict due to the insufficient intensity of violence or organisation of the non-State armed group, this would not create a legal void. Under the umbrella of Article 2(2) of the AP II, namely 'internal disturbances and tensions, such as riots, isolated and sporadic acts of violence and other acts of a similar nature, ${ }^{53}$ law enforcement appears to be the appropriate paradigm for legal regulation. Under it, any (terrorist) attack against military objects or civilian populations are automatically deemed unlawful. ${ }^{54}$

Therefore, the overarching question is where do we draw a dividing line between IHL and law enforcement? Apparently, establishing the beginning of a NIAC is the starting point. Attached to it is the blurring of such a legal determination due to the characteristics of terrorism we have discussed. But before attempting to offer an answer, we need to appreciate the escalated frustration due to the mere choice by the State for a law enforcement paradigm.

48 IHRL is also applicable during an armed conflict. IHL and IHRL rules should be interpreted harmoniously as far as possible. See Legality of the Threat or Use of Nuclear Weapons, Advisory Opinion, ICJ. Reports 1996, 226; Legal Consequences of the Construction of a Wall in the Occupied Palestinian Territory, Advisory Opinion, ICJ. Reports 2004, 136; Human Rights Committee, General Comment 31, Nature of the General Legal Obligation on States Parties to the Covenant, UN Doc. CCPR/C/21/Rev.1/Add.13 (2004), para 11. For an opposite view, see e.g., Gill, supra nt 1, 251 - 252.

49 Article 35 of AP I; Article 8(b)(xx) of the Rome Statue United; UN Secretary General (UNSG), Secretary-General's Bulletin: Observance by United Nations Forces of International Humanitarian Law, No. ST/SGB/1999/13, 6 August 1999, para 6.1; and ICRC Customary IHL, Rules 12, 70—71.

50 ICRC, 'Report on International Humanitarian Law and the Challenges of Contemporary Armed Conflicts', 31st International Conference of the Red Cross and Red Crescent (2011) 48.

51 Pejić, J, 'Counter-terrorism and The Rule of Law Framework' in María Salinas de Frías, A, Samuel, A, and White, N, (eds.), Counter-Terrorism: International Law and Practice (2012), 173. See also AP II, Articles 4, 13.

52 Prosecutor v. Brima (Appeals Chamber Judgment) SCSL-2004-16-A (22 February 2008) para 172; Prosecutor v. Sesay (Trial Chamber Judgment) SCSL-04-15-T (2 March 2009) para. 677; Prosecutor v. Taylor (Appeals Chamber Judgment) SCSL-2003-01-A (26 April 2012) para 1979.

53 AP II, Article 1(2).

54 ICRC, supra nt 50, 49. 


\section{The Frustration of Applicable Paradigms in Response to Terrorism}

The frustration and sometimes incorrect application of paradigms is attributable to the State's unwillingness to recognise the applicability of IHL. With less control over the situation, a State fighting in accordance with IHL rules is forced to recognise the nonState armed group as a legitimate party to a NIAC. The intensity threshold required for a NIAC also implies the State's inability to contain the spiralling violence within its own territory. As a consequence, IHL categorically endorses the legal entitlement of the nonState armed group to use lethal force to advance their military position against State agents under jus in bello. ${ }^{55}$ Hence, States generally prefer a domestic law enforcement framework, which provides more latitude in their criminalising and prosecuting 'terrorists', so to speak. ${ }^{56}$

Still, in recent decades, we have seen a gradual change in the attitude of States when it comes to their extraterritorial counter-terrorism operations. The decision of the United States to conduct drone strikes in Afghanistan, for instance, was made coupled with an IHL-regulated mandate ${ }^{57}$ One plausible explanation is that IHL permits the use of lethal force provided that proportionality is satisfied, whereas a law enforcement paradigm would almost certainly render such lethal force unlawful under IHRL.

We have noted that the determination of the existence of a NIAC is ex post facto. Insofar as counter-terrorism responses are concerned, it is easier for States to put in place law enforcement within the domestic legal bounds, regardless of whether an armed conflict could have been established. The borderline situations are exemplified by the law enforcement units deployed by the United Kingdom in Northern Ireland to curb 'The Trouble' movement until the 1998 Belfast Agreement, as well as Russia's punitive measures against the Chechen insurgents participating in the hostilities.

To add to the complexity, there are other situations where States would co-apply both IHL and law enforcement. One example are the Israel/Palestine checkpoints, an occupation case which attracts the application of IHL. Nonetheless, the Rules of Engagement for the Israel Defence Forces regulate lethal force through the law of selfdefence, as imaginably influenced by IHRL. This has dismissed the soldier's obligation to apply status-based judgment under IHL. Likewise, the Israel Supreme Court has demanded the 'capture-before-kill' principle in targeted killing cases, making specific legal issues in the occupied territory more aligned to IHRL. ${ }^{58}$

Another example is the co-execution of conducting hostilities and law enforcement operations by the same State agents in Colombia. During the conflict with the Revolutionary Armed Forces of Colombia (FARC), the Colombian armed forces were provided with multi-coloured cards instructing whether the current operation falls within the context of the NIAC or law enforcement. ${ }^{59}$ It becomes extremely difficult to

55 On the equality of belligerents, see for example, Clapham and Gaeta, supra note 47,52 . See also, Chadwick supra nt 40,8 .

56 However, in certain cases, States may resort to law enforcement due to their lack of capacity to implement IHL. In the case of Al-Shabaab, Somalia's police and security forces were deployed while the spill-over violence was tackled by Uganda's military troops cross the border. See e.g. United States Department of State, Country Reports on Terrorism 2015 - Somalia (2 June 2016).

57 Dorsey, J, and Paulussen, C, "The Boundaries of the Battlefield: A Critical Look at the Legal Paradigms and Rules in Countering Terrorism" (ICCT Research Paper, April 2013) 11.

58 The Public Committee against Torture v. The Government of Israel ("Targeted Killings"), Israeli Supreme Court, sitting as the High Court of Justice (11 December 2005). This requirement is also due to the application of IHRL in occupation cases where effective control is shown. See e.g., Milanović, M, "When to Kill and When to Capture?" European Journal of International Law Blog, (2011); Goodman, R "The Power to Kill or Capture Enemy Combatants", European Journal of International Law 24 (2013).

59 Carlos Gomez, J, "Twenty-First-Century Challenges: The Use of Military Forces to Combat Criminal 
draw a dividing line between those military operations executed against insurgents in the NIAC, and those executed against ordinary criminals. ${ }^{60}$ Even though a State may wish to deploy law enforcement agents in an armed conflict, they cannot opt out of IHL rules. ${ }^{61}$ However, the State may run the risk of losing IHL protections to law enforcement agents if those agents are considered part of the de facto armed forces by IHL. ${ }^{62}$

\section{The Dividing Line Between IHL and Law Enforcement}

Returning to our point of departure, namely, where to draw the dividing line between the two paradigms, it is necessary to assess the validity of the claim by States that a situation of terrorism of itself can negatively impact the applicability of IHL. In doing so, it is perhaps most helpful to examine the role of terrorism based on the two-pronged test in Tadić.

\section{A. Identification of Parties}

Often times, States tend to qualify a non-State armed group as a 'terrorist group' so as to delegitimize the group, deny the existence of a NIAC, and reject the applicability of IHL. This trend has led to increasing criminalization under the national legal framework without amnesty. On the contrary, Common Article 3 puts the emphasis that the applicability of IHL rules 'shall not affect the legal status of the Parties to the conflict.' In the context of a NIAC, States are encouraged to grant the 'broadest possible amnesty to persons who have participated in the armed conflict. ${ }^{63}$ In fact, the Draft Comprehensive Convention against International Terrorism preserves the distinction between prosecution of terrorism in the context of an armed conflict and in a context that falls short of an armed conflict. Like other Conventions prohibiting terrorism, the Draft Comprehensive Convention contains an exemption clause, providing that '[n]othing in the present Convention shall affect other rights, obligations and responsibilities of States, peoples and individuals under [...] international humanitarian law. ${ }^{64}$

Parallel to the indicators identified in Haradinaj, the Trial Chamber in the Boškoski case again emphasized that the non-State armed group must have 'some hierarchical structure' and must be able to implement the basic obligations of Common Article $3 .^{65}$ In any case, if a State believes that an alleged terrorist group does not possess a sufficient

Threats", International Law Studies 88 (2012) 279, 285-86.

60 Dinstein, Y, "Concluding Remarks on Non-International Armed Conflicts" in Watkin, K, and Norris, AJ, eds., Non-International Armed Conflict in the Twenty-first Century, International Law Studies 88 (2012) 414.

61 In a NIAC, it is up to each nation to decide whether existing law enforcement agencies should continue to carry out their responsibilities: see e.g., ICRC, Violence and Use of Force, supra nt 33, 41. In addition, there has been a noteworthy trend that local police use drones within the State's border: see e.g., Kearney, K, "Police in Northern Ireland consider using mini drones" (BBC, 16 November 2011). The US Federal Aviation Authority Modernization and Reform Act of 2012 grants increased powers to local police forces across the USA to use their own drones.

62 ICRC, To Serve and to Protect, supra nt 34, 394. c.f. subject to two exceptions: (1) Article 43(3) of AP I provides that ' $[\mathrm{w}]$ henever a Party to a conflict incorporates [... an] armed law enforcement agency into its armed forces it shall so notify the other Parties to the conflict'. (2) Direct Participation in Hostilities.

63 AP II, Article 6 (5).

64 Draft Comprehensive Convention against International Terrorism Article 20(1). See also Article 4(2) of the International Convention for the Suppression of Acts of Nuclear Terrorism; and Article 19(2) of the International Convention for the Suppression of Terrorist Bombings.

65 ICTY, Prosecutor v Boskoski (Trial Chamber Judgment) ICTY-04-82-T (10 July 2008) para 195. 
degree of organisation, they cannot conduct military operations against it. Clearly, they cannot create a war against a non-existing adversary party. ${ }^{66}$

It bears repeating that the assessment of the degree of the group's organization must objectively consider the facts on the ground.$^{67}$ In this sense, Colombia and Ireland are two cases in point.

\section{i. Fuerzas Armadas Revolucionarias de Colombia (FARC)}

In the case of Colombia, the government has repeatedly denied the existence of a NIAC on its territory, opting to define the hostilities as part of a 'war on terror' instead. On the contrary, numerous international bodies, including the ICRC and Amnesty International have consistently defined the situation in Colombia as a NIAC and the FARC as an 'armed opposition group. ${ }^{68}$ In order to establish its jurisdiction, the International Criminal Court (ICC) had unequivocally concluded 'a reasonable basis to believe that war crimes [...] have been committed in the context of the non-international armed conflict in Colombia' between November 2009 and November 2002. ${ }^{69}$

Legally speaking, despite the frequent listing of the FARC as a 'terrorist organisation', ${ }^{70}$ it does not undermine the factual determination that the group 'exhibits a sufficient degree of organisation, and have engaged in sustained military hostilities against the Colombian government. ${ }^{71}$ The FARC had a well-established command structure with a Commander in Chief, Secretariat, Central High Command, Bloc, Front, Column, Company, Guerrilla and Squad. It also possessed a system for firearms and ammunition, effective control over part of the territory of Colombia, and official Rules of Engagement. This degree of organisation had enabled the FARC to carry out attacks causing civilian damages. In a period of 10 years, between 15,000 and 30,000 people have been victims of enforced disappearances, while more than 20,000 people were kidnapped or taken hostage. ${ }^{72}$ More than 70,000 people, the vast majority of whom were civilians, have been killed as a result of the conflict. ${ }^{73}$

\section{ii. Irish Republican Army (IRA)}

'The Troubles' movement in Northern Ireland is another prime example of how States subjectively rejected the status of a non-State armed group, denied the applicability of IHL, and adopted a law enforcement paradigm to counter terrorism. The IRA has been labelled as 'terrorist' since the 1970s when it was founded. ${ }^{74}$ The group however explicitly considered themselves as a national liberation movement engaged in a war for self-

${ }^{66}$ Ojeda, S, 'Global Counter-Terrorism must not Overlook the Rule of War', Humanitarian Law \& Policy, 13 December 2016.

67 Milanović, supra nt 27, 188.

68 Amnesty International, "Leave us in Peace!": Targeting Civilians in Colombia's Internal Armed Conflict' (2008), 4; ICRC, "Summary Report: Afghanistan, Colombia, Democratic Republic of the Congo, Georgia, Haiti, Lebanon, Liberia and the Philippines: Opinion Survey and In-Depth Research, 2009" (November 2009) 24.

69 ICC Office of the Prosecutor, "Report on Preliminary Examination Activities 2016" (14 November 2016), para 138; ICC Office of the Prosecutor, "Situation in Colombia, Interim Report" (November 2012), para 128.

70 These include the U.S. Department of State's List of Foreign Terrorist Organisation since 10 August 1997, the European Union terrorist list enlisting the FARC in June 2002, and the United Kingdom "terror list" since 2001.

${ }^{71}$ ICC Office of the Prosecutor, "Situation in Colombia, Interim Report" (November 2012), para 128.

72 Ibid.

73 Ibid.

74 Turns, D, "The "War on Terror" Through British and International Humanitarian Law Eyes: Comparative Perspective on Selected Legal Issues' (2007) 10 New York City Law Review, 445. 
determination from a foreign army. ${ }^{75}$ Even though the United Kingdom Home Secretary and the Prime Minister of Northern Ireland once stated that the authorities were 'at war' with the IRA, they categorically denied the existence of an armed conflict. ${ }^{76} \mathrm{In}$ constructing their narrative, the British government called the violence a 'civil conflict' of a strong criminal nature, which the national law enforcement agents were authorised to deal with. ${ }^{77}$

This was followed by the United Kingdom's ratification of the 1949 Geneva Conventions and the Additional Protocols. At the same time, it produced an understanding that an armed conflict excludes ordinary crimes, including acts of terrorism. ${ }^{78}$ The understanding failed to contemplate that terrorism may occur in times of armed conflict. ${ }^{79}$

It was obvious that the IRA had an effective command structure, including an Army Council. They were also able to conduct armed operations in Northern Ireland, Britain and other parts of Western Europe, and they had control over certain parts of Londonderry and Belfast. ${ }^{80}$ Their degree of organisation is also manifested in the ability to ultimately declare a ceasefire subsequent to the Canary Wharf and Manchester bombings in $1997 .{ }^{81}$ Later on, these factors were countered by the fragmentation of the group in 1969 due to conflicting ideologies. Hence, it had become difficult to identify the party participating in the hostilities. ${ }^{82}$ But insofar as establishing the beginning of a NIAC is concerned, the proper paradigm to subject both parties in their operations appeared to be IHL. ${ }^{83}$

\section{B. Intensity of Violence}

The legal existence of a NIAC requires 'protracted armed violence' which denotes a minimum level of intensity to distinguish itself from internal disturbances ${ }^{84}$ In the case of Haradinaj, the term 'protracted armed violence' has also been interpreted as 'referring more to the intensity of the armed violence than to its duration. ${ }^{85}$ With regard to the increasing use of counter-terrorism law enforcement, it is helpful to recall that the ICTY,

$75 I d, 446$.

76 Ibid. Also see, Shanahan, T, Provisional Irish Republican Army and the Morality of Terrorism (Edinburgh University Press 2008) 95.

77 Ibid, 96.

78 Turns, supra nt 74, 445, 449. The United Kingdom will not, in relation to any situation in which it is itself involved, consider itself bound in consequence of any declaration purporting to be made under [Article 96(3) of the Protocol] unless the United Kingdom shall have expressly recognised that it has been made by a body which is genuinely an authority representing a people engaged in an armed conflict of the type to which [Article 1(4)] applies.

79 O'Connell, M E, "The Choice of Law Against Terrorism" 4 Journal of National Security Law and Policy (2010) 749, 348.

80 Turns, supra nt 74, 445, 450; Dewar, M, The British Army in Northern Ireland (Arms and Armour 1996) 69-70.

81 Akande, supra nt 18, 130-133.

82 Shanahan, supra nt 76, 98.

83 Timothy Shanahan, Provisional Irish Republican Army and the Morality of Terrorism (Edinburgh University Press 2008) 97.

84 Article 1(2) of AP II states 'This Protocol shall not apply to situations of internal disturbances and tensions, such as riots, isolated and sporadic acts of violence and other acts of a similar nature, as not being armed conflicts'. Also see, Hessel, D, Shu, J, and Weiner, S, 'Below the Threshold: The Law Governing the Use of Non-State Actors in the Absence of a Non-International Armed Conflict' (2015) Yale Law School Center for Global Legal Challenges, 2; See Tadić, supra nt 11, para 70.

85 Haradinaj et al., supra nt 11, para 49. 
in 1997, already attempted to distinguish armed conflicts from 'banditry, unorganized and short-lived insurrections, or terrorist activities. ${ }^{186}$

Adding one clarification on this point, Dinstein viewed that this reference to 'terrorist activities' should be taken as relating not to the nature of the acts but to their sporadic incidence. It is only when terrorist activities do not meet the required preconditions of a NIAC that they would move into a legal classification other than IHL. ${ }^{87}$ In other words, the fact that an act of violence is terrorist in nature cannot be taken on its own to undermine or aggravate the intensity of violence. In this sense, the Boškoski judgment acknowledged that terrorist acts may also be factored in to the intensity threshold. ${ }^{88}$ In these situations the intensity threshold is not crossed, meaning that the violence in question must be alternatively subjected to law enforcement and its associated regimes, such as IHRL, and that non-State actors cannot be targeted militarily as combatants.

Although terrorism commonly signifies sporadic attacks, the global picture of the overall violence should not be underestimated. Rather, the level of intensity should be judged for the entire period of hostilities. ${ }^{89}$ One difficulty is that civilian casualties indicating the intensity of violence are often attributable to multiple responsible non-State armed groups in the region. In the case of Syria, an individual assessment of the conflicts would not cross the threshold. This explains why, while more than 16,000 civilians had been killed as of March 2011, the ICRC only classified the protracted violence in Syria as meeting the intensity threshold in July $2012 .{ }^{90}$ This is essentially a question of attributability. The prevailing view is that one cannot add up all associated violence from different non-State armed groups, or from the same group but without an established nexus to the conflict. ${ }^{91}$

Finally, terrorist acts may also be conducted by a party to an armed conflict but fall outside the context of that conflict. Only terrorist acts with sufficient connection to that armed conflict are governed by IHL. ${ }^{92}$ In this way, whether IHL or law enforcement should be the guiding paradigm does not dismiss the fact that their applicability still remains issue-specific. In the case of Chechnya, the Russian constitutional court determined that AP II was applicable to the first Chechen conflict. ${ }^{93}$ Russia has denied the applicability of IHL to the second Chechen war, arguing that the authorities were merely targeting terrorism and criminal acts. When the case of Finogenov v. Russia

86 ICTY, Prosecutor v Ljube Boškoski and Johan Tarčulovski, (Trial Chamber Judgement) IT- 04-82-T (10 July 2008) 184-90.

87 Dinstein, Y, Non-International Armed Conflicts in International Law 108-14 (Cambridge University Press 2014) 34.

88 ICTY, Prosecutor v. Ljube Boškoski and Johan Tarčulovski (Trial Chamber Judgement) ICTY- 04-82-T (10 July 2008) 184-190.

89 ICTY, Prosecutor v. Ljube Boškoski and Johan Tarčulovski (Trial Chamber Judgement) ICTY- 04-82-T (10 July 2008) 128-9.

90 Caphalm, A, et al., The 1949 Geneva Conventions: A Commentary (Oxford University Press 2015), 412. Also see, BBC News, 'Syria in Civil War, Red Cross Says,' July 2012, at < http://www.bbc.com/news/world-middle-east-18849362 > (accessed 18 November 2017).

91 Pejić, J, 'Terrorist Acts and Groups: A Role for International Law?' 75 British Yearbook of International Law (2004) 86, 86-87.

92 Saul, B, "Terrorism and international humanitarian law," in Saul, B, Research Handbook on International Law and Terrorism (Edward Elgar Publishing 2014). 'Not all acts of terrorism in a territory affected by armed conflict will comprise part of that conflict'.

93 Judgment of the Constitutional Court of the Russian Federation of 31 July 1995 on the constitutionality of the Presidential Decrees and the Resolutions of the Federal Government concerning the situation in Chechnya, European Commission for Democracy through Law of the Council of Europe, CDL-INF (96) 1. 
reached the European Court of Human Rights, the Court analysed the violations in IHRL terms, not because Russia had unilaterally classified the situation as domestic, but because the hostage-taking of the Moscow theatre occurred outside the battlefield. ${ }^{94} \mathrm{Of}$ course, this approach was not without criticism. ${ }^{95}$

\section{Conclusion}

The determination of the applicable paradigm drastically impacts who a State may or may not kill. The extensive ramifications continue beyond the hostilities to the criminal proceedings that seek to determine post-conflict accountability. Given the increasing amount of intra-State wars, tactics of terrorism and civilian casualties, the stake now is higher than ever.

This article has shown that the determination of NIAC is not without its inherent difficulties. This is yet further frustrated by not only the characteristics of terrorism, but also the intentional use of the law enforcement paradigm at the disposal of States in lieu of IHL. But as we have seen, terrorist acts of violence do not simply fall within the hands of law enforcement because they are terrorist in nature. Judicial assessment remains as such that it resorts to the factual determination on the ground. In this sense, the impact of terrorism on the legal establishment of armed conflicts and hence the applicability of IHL, if any, has proven minimal.

www.grojil.org

ECtHR, Finogenov and Others v. Russia, App. No. 18299/03 (10 December 2011), para 220.

95 'If one considers that IHL applied to such a situation given that this event had a clear nexus with the Second Chechen War, then the use of a gas in this situation would have been considered unlawful under IHL [...] In that case, the lack of reference to IHL did not allow affording a better protection to individuals in a situation of armed conflict.' Gowlland-Debbas V, and Gaggioli G, "The Relationship Between International Human Rights and Humanitarian Law", in Kolb, R, and Goggioli, G, Research Handbook on Human Rights and Humanitarian Law (Edward Elgar Publishing 2013). 